\title{
Why is integration so difficult? Shifting roles of ethics and three idioms of thinking about science, technology and society
}

\author{
Rune Nydal
}

Department of Philosophy \& Religious Studies, Norwegian University of Science and Technology, Trondheim, rune.nydal@ntnu.no

(cc) BY
This is an open access article distributed under the terms of the Creative Commons Attribution 4.0 Interna-
tional License, which permits unrestricted use, distribution, and reproduction in any medium, provided the
original author and source are credited.

Contemporary science and technology research is now expected to become more responsible by collaborating with social scientists and scholars from the humanities. This paper suggests a frame explaining why these calls for 'integration' are seen as appropriate across sectors, even though there are no shared understandings of how proper integration should take place. The call for integration is understood as a response to shifting roles of ethics within research structures that have followed shifts in modes of knowledge production. This paper suggests integration is difficult because it challenges the modern normative division of labour that affects professional identities across sectors. Working out modes of integration is an important venue for determining alternative professional identities and viable alternative understandings of research. This paper discusses the matter with reference to three successive idioms for thinking about science, technology and society as discussed in the literature. These are representational, performative and co-production idioms.

Keywords: Integration, collaboration, representational idiom, performative idiom, co-production idiom

\section{The role of ethics in research structures}

It is no longer unusual for large-scale science initiatives seek to include or 'integrate' research from both the humanities and social sciences. Promoters of this integration often seek normative justifications and express a need to engage in ethical and political research activities as 'part of large scientific initiatives. The Human Genome Project (HGP) was a pioneer in this regard because it installed "[b]ioethics inside the beltway" as Erik Meslin et al. (1997:291) put it, by providing a "novel approach to the simultaneous study of ethical, legal, and social issues and basic scientific issues". Similar programmes have since been pursued in Canada and different countries in Europe, such as Norway, and are supported by a number of policy reports world-wide (including NSF 2001, RNA 2004, RAE 2004, NFR 2005, EC 2004 \& 2007). Currently, the integration of social and humanist research into large scientific initiatives tends to be promoted under the heading of 'responsibility' - which considers integration to be critical in ensuring Responsible Research and Innovation (RRI) (EC 2013). 
The question of why the HGP actually came to include an 'ELSI' research programme, as it was called, is complex. The ELSI programme did more than express normative concerns about the HGP, because the HGP was controversial across all disciplines and had to win political, public and scientific support (Cook-Deegan 1995, Roberts 2001). ELSI programs have existed for twenty-five years now, but are still at an early stage, where there is still debate over basic normative questions of what justifies these programmes, what forms they should take and what one can hope to achieve (Rip 2014, Owen et al. 2013). It is certainly true that, as an editorial in Nature stated, it will take time to assess the value of these "fresh approaches" (Nature, 2009).

This paper analyses the normative reasons for integration. Integration is understood here as a deliberate attempt to bring the works of the humanities and social sciences into productive relationships with today's complex and multi-faceted technological and scientific research, because this research is still conducted in traditional ways that do not reflect current realities. The paper assumes that the call for integration rests on some normative diagnosis that calls into question traditional modes of conducting research. However, because we lack unifying and clearly articulated alternatives, there is no unified or clearly articulated analysis of the deficiencies that integration is supposed to address. Nevertheless, the fact that these large research programmes continue to be financed suggests some overlapping agreement across sectors of the appropriateness of experimenting with new and fresh approaches. But at the same time, this integration is recognized as difficult. The most recent research calls from the Research Council of Norway explicitly included requests for experiments with integration that could build new forms of expertise and research capacities that are not found in the current research and innovation system (see NFR 2008, NFR 2014).

The question of why integration is so difficult has become an urgent matter given the expectations of integration. This article addresses the issue and interprets the integration trend as a response to shifting roles of ethics within research structures. Integration is difficult because it addresses basic questions of what role research should play in contemporary societies. The shifting role of ethics is discussed with reference to three successive idioms of science that have been articulated by historians, sociologists and philosophers of science. The representational idiom is dominant, and understands science as an activity that aims to produce true representations. This idiom, which has dominated the philosophy of science up until late 1970s, casts science in terms that do not support integration; on the contrary, it enforces a professional division of labour between physical and natural scientists on the one hand and social scientists and researchers from the humanities on the other. The performative idiom, in contrast, represents a critique of the no-integration ideal of the representational idiom. This idiom was articulated during the 1980s and 1990s in circles where the sciences were studied empirically. The third idiom, the co-production idiom, is considered by this paper as the idiom that increasingly informs science policy, and that encourages rather than counteracts integration.

This paper uses these three theoretical idioms as a way to explore the attraction and difficulty of integration. The three idioms should not be understood as ahistoric alternatives, however, but rather as reflecting a shift in the role of ethics within research structures. As has been discussed elsewhere (Nydal 2005), scholars from the history and philosophy of science have historically played an important role in articulating changes in practices along with the norms that accompany these changes. The representational idiom, in this account, has been so dominant that it has proven difficult to formulate alternatives, and the challenges of integration are here understood as a result of this dominance. The notion of integration is 
interesting because it does not primarily draw attention to theoretical issues, but rather to practical matters of how work should actually be done.

\section{Shifting role of ethics within research structures}

The need to 'integrate ethics' has been analysed and discussed in bioethical circles since the early 1980s. The standard story of the rise of bioethics (see, for example, Boyle 1984, Toulmin 1982, Brant 2002) is that the field of applied ethics was sparked by a critique of moral philosophers who were seen as not able, or willing, to address practical problems. Ethicists were occupied with meta-ethical issues, and clarifying meanings of ethical terms and principles of justifications of ethical judgements. As a result, moral philosophers did not engage in practical problems at a time when newspapers were flagging a diversity of urgent ethical issues such as organ transplantation, selective abortion, research ethics, nuclear weapons, women's rights and racism. Bioethics arose, according to these accounts, as an interdisciplinary field that had to establish novel research modes for ethics. Ethics, and the role of the humanities in general, as Boyle (1984) suggested thirty years ago, was not only a problem for moral philosophers - it had become something of a problem for the universities. What should the role of ethics be within research structures, and what form should it take? The HGP's ELSI research programme offered an important arena for exploring new roles, in part because it was criticized by a number of STS scholars for its lack of interventionist capacity. As it was structured, it was downstream, and oriented toward consequences and disciplinary actions (Winner 2004, Williams 2006, Fisher 2006). Whether the critique was reasonable or not is not the issue here. Instead, what is of interest is the way the critique focused on the same issues raised by previous discussions in applied ethics concerning the proper role of the humanities, and now the social sciences, in research structures. The standard ELSI critique was a critique of failed integration, and supported a call for humanists and social scientists to take on a responsible role as co-constructors in a more participatory and integrative way than they had been used to (Rip et al. 1995, Guston and Sarewitz 2002, Balmer et al. 2012).

These new roles, however, are unfamiliar and have to be shaped. There nevertheless seems to be quite high expectations of what one can hope to achieve in inventing new integrative practices.

\section{High expectations}

The following figure (see Fig.1) appeared in a research programme plan from the Research Council of Norway (Nano2021).

The programme plan presents three pillars as key to research strategies for Norwegian investments in nanotechnology and advanced materials. The figure suggests that the builders and users, illustrated in the research - industry - society triangle, need be aligned and brought into productive cooperative relationships. Although sectorial activities actually do interact, as the programme plan seems to suggest, this is not necessarily the result of a reflective and responsible process, in the words of John Schot and Ari Rip (1996). This is where the third RRI pillar plays a key role, because it is supposed to make explicit and tackle

ethical and social aspects of the development, production and application of nanotechnology. Activities will provide the knowledge platform needed for responsible, sustainable technology development as well as input for legislation in and regulation of the technology area (Nano2021:10).

The research programme then, is envisioned in a broader social context where

Nydal, R. Etikk i praksis. Nord J Appl Ethics (2015), 9 [1], 21-36 
$[\mathrm{K}]$ nowledge and technology are to be developed in close cooperation with industry players to satisfy society's needs for know-how and innovative solutions. Knowledge and technology will also be developed in a manner that harmonises with social values and with an emphasis on responsible implementation of solutions (Nano2021:10).

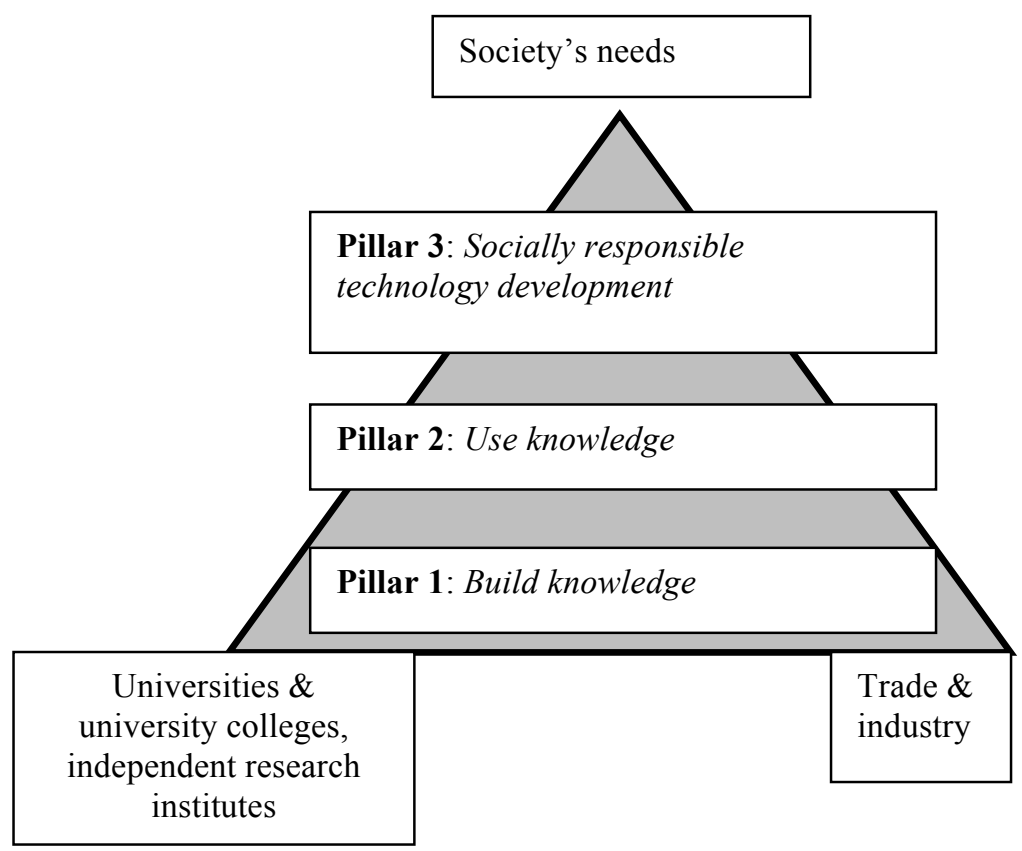

Figure 1. "Interplay between the three pillars of the programme" (Reproduced figure found in Nano2021:10]

The programme plan reflects some recognition of the need for integration. Some knowledge produced in the humanities and social sciences - one might say - is acknowledged as missing or not adequately factored into the standard ways of organizing scientific and technological research programmes. The programme plan may also be said to carry a normative diagnosis; the ways that we are accustomed to think and talk about science programmes like Nano2021 - along with established ideals for how to do this well - no longer seem to suffice. The "knowledge platform needed for responsible" technology development, even if it is out there, does not translate or flow easily into the scientific enterprise.

It is quite striking, given the high expectations of integration, how fuzzy the vision of integration is. There are few methods or exemplary cases that show how to carry out RRI or ELSA strategies of the sort that are called for. RRI remains at an early stage. Furthermore, the analyses presented by proponents of why this integration is needed are neither uniform nor clearly articulated and there are sometimes even strong disagreements across scholarly communities about what is meant by the notion of integration (Myskja et al. 2014). The push for integration, like that expressed in the Nano2021 programme plan, may suggest a somewhat collective experience that integration is worth pursuing, even though we do not know how to carry it out and what is to be achieved.

This paper suggests that the three successive idioms of science reflect this exact problem. The difficulties and attractions of integration reflect changes in how we understand the sciences, and more importantly, the commitments and responsibilities that come with pursuing scientific work. Demands for integrating the humanities and social sciences into 
scientific research raise questions about our common, widely shared and taken-for-granted understanding of science.

\section{Changing ideals}

Fifteen years ago, Science published a well-known essay by John Ziman (1998) that posed the question: "Why must scientists become more ethically sensitive than they used to be?" In the 1950s, when Ziman was a young physics student, he notes that there was hardly any focus on ethics; on the contrary, the common understanding of science included a "no ethics principle". Ethics simply "did not figure regularly in public discourse about science". The no ethics principle does not imply that there were no ethical codes of conduct regulating good practices, of course, but that these codes, like the Mertonian (1942), eliminated conventional ethical considerations (i.e. what we in ordinary language would recognize as the ethical and political issues of science) from the realm of the scientists' professional identity.

Ziman's point is illustrated in a 1952 speech discussed by Torben Hviid Nielsen. The quote below is from a speech given to new students by University of Oslo Rector Otto Lous Mohr, at about the same time as Ziman was becoming a physicist.

The scientist pursues knowledge. He does not patent his discoveries; he does not exploit them for personal gain. He only demands a reasonable compensation that will ensure his ability to concentrated, the inner calmness that conditions his research (my translation, Nielsen 2006)).

This statement is framed by an understanding of science that does not encourage integration. On the contrary, it conveys an image of scientists as professionals who need to isolate themselves in order to avoid distraction and worldly concerns. The rector, in encouraging and motivating new students to look forward to what they are to become, paints a picture of a scientist in terms that now seem rather outmoded. His portrayal of the scientist is marked by a normative understanding of science: it includes an interpretation of why science is worth doing, and what we need scientists for. This understanding of science consequently describes what new students should take pride in and provides directions for what their main responsibilities and duties are in becoming a scientist. In short, it offers scientists an ideal and an ethos.

Ziman notes that expectations for scientists have changed. "Nowadays", scientists are expected to be more concerned with ethics, a concern reflected in how "the ethics of science occupies [...] media [...] energizes scholarly books, journals, conferences and curricula" (Ziman 1998: 1813). And, we could now add, ethical concerns are also included in research programmes. Today, we would be surprised if university rectors talked like Mohr. We would hardly resist smiling condescendingly. More importantly, we would not expect our rectors to want to express themselves this way; they would not believe in or endorse the ideals it embodies. What is disturbing, however, is not that our current rector would not endorse the ideals of the past, but that we do not quite know how to formulate the ideals of the present. Imagine yourself a rector, what would you say to the new generation to motivate them to do science? What is it about this thing called science they should take pride in being part of? And how, really, does that affect a scientist's responsibilities and duties? Can we propose an updated and credible ideal and ethos for science?

The call for integration is not only as a symptom of how the sciences have changed, but also a challenge that gives direction to the fields that study science. An important assumption 
of this paper, following Ziman and others, is that the sciences have changed in radical ways that call for re-articulations of good scientific practice. In the following, I discuss three successive idioms of science and how they reflect both historical changes in science and how philosophers, sociologists, historians and anthropologists have come to articulate these changes.

\section{The representational, performative and co-production idioms}

Dictionaries identify idiomatic phrases or expressions as those that would be typically used to characterize a particular activity. Idiomatic phrases come naturally to native speakers, because they express a common understanding.

When Mohr states that "[T]he scientist pursues knowledge" (as quoted above) he is expressing himself in a way that comes naturally to him as a scientist - as a "native speaker" who knows what science is. As a rector, he can speak with authority about what scientists do, at least as long as his peers believe what he says is accurate. His short sentence expresses the no-ethics principle in a condensed form, and has ramifications for what is expected of the scientist, as is made more evident in the subsequent sentences. One could say that these expressions are idiomatic in as much as they capture characteristic features of the activity, along with commitments to the codes of conduct of good practice for scientists.

Ziman also appeals to such an understanding in discussing Merton's norms as he addresses scientific peers in his 1998 essay in Science. Merton, after all, "provides the best theoretical framework for an understanding of how these practices interact to produce the sort of knowledge that we recognize as peculiarly 'scientific"' (1998: 1813). Skilled scientists would recognize that the central practices of their work, such as "peer review, respect for priority of discovery, comprehensive citation of literature, meritocratic preferment on the basis of research performance, and so on", would be adequately described by Merton. These practices and the relations between them have not been systematically formalized but have emerged among scientists who are committed to the task of 'pursuing knowledge'. These practices are both adhered to by scientists, and regulate their behaviour. Although scientists do not necessarily have a well-articulated and consistent theory of science, they share a way of talking about science that communicates and maintains such an understanding.

Idiomatic expressions capture what we recognize as "peculiarly 'scientific" that includes an understanding of the point of the activity and what makes it worth doing. Idiomatic expressions thus embody ideals of what scientists should aspire to become, and consequently what should be manifested in implicit and explicit ideals of what scientists find honourable and praiseworthy, as well as unavoidable commitments and duties.

\section{Three idioms and shifting normative orders}

The three idioms offer three different theoretical perspectives on science that reflect historical changes since the 1950s. One key role of the history and philosophy of science is to help articulate these changes and accompanying norms of good practice.

I will emphasize two aspects of the three idioms in the following. First, I will focus on as the representational idiom since it is a dominant understanding to which it has been difficult to formulate alternatives. Second, the normative commitments to the representational idiom are important here as they are critical in understanding the challenges of integration. The representational idiom, in this view, casts science as a 'no-integration' ideal, one that is 
criticized in the performative idiom. In contrast, integration appears to be a core challenge in the image of science that emerges in the co-production idiom.

\section{The representational idiom and the "no-integration" ideal}

In The Mangle of Practice, Andrew Pickering suggests that we refer to the dominant idiom as the 'representational idiom' while he also presents an alternative, the 'performative idiom'. The representational idiom, Pickering says, "casts science as, above all, an activity that seeks to represent nature, to produce knowledge that maps, mirrors, or corresponds to how the world really is" (Pickering 1995:5).

This is, in other words, an idiom of science framed by classical epistemology that has played a dominating role in Western thought in general (see, for example, Rorty 1980 and Taylor 1995) and for the understanding of the sciences in particular (see, for example, Lynch 1993 and Hacking 1983). What is worth noting here is that the representational idiom also established methodological guidelines for how philosophers of science should approach their work; where they turned their attention in studying, evaluating and assessing science and technology. Hacking (1983) says the interests of philosophers of science until the late 1970s were dominated by 'theory-oriented' terms such as 'discoveries', 'facts', 'theoretical entities', 'scientific objects', 'theory choice' or 'observations'. These concepts were central topics because the field tended to conflate knowledge with scientific theories - or representations of the world. This bias towards representing, at the expense of intervening, in Hacking's terms, follows from the dominant epistemological tradition of Western thought.

The critique of classical epistemology is a recurrent topic among scholars who are critical of the philosophy of science tradition. This paper draws on Charles Taylor's critique, as he focuses on this epistemological tradition's formative role on normative thinking in our culture at large. In Taylor's account in "Philosophy and its History" (1984), the epistemological tradition frames a common cultural background for Western societies because it has simultaneously modelled the standards of good practice of a range of different practices, not only science. In general, Western legitimizing discourses tend to be 'epistemological modelled', in Taylor's words. The epistemological model is a model in the sense of functioning as an "organising principle for a wide range of practices in which we think and act and deal with the world" (Taylor 1984:20). Classical epistemology is no less than a "hydra whose serpentine heads wreak havoc throughout the intellectual culture of modernity" (Taylor 1984: 20). There are two important aspects here.

First, the representational idiom, given Taylor's analysis, casts science in terms maintained by shared cultural commitments to the ways we have come to model, or organize our societies. From this perspective, the 'theory-oriented' image of science is not to be regarded as a philosophical invention one could easily dismiss and leave everything else unchanged. "The image of science by which we are now possessed", as Thomas Kuhn famously put it in his opening sentence of The Structure of Scientific Revolutions, is epistemologically modelled, according to Taylor's view, along lines that permeate other central practices in our societies. As an organizing principle, the epistemological model cements a normative order by which we live and to which as professionals we are committed. Any attempt to rethink science would potentially risk coming in conflict with this normative order, and could jeopardize professional identities.

Second, because classical epistemology has become entrenched in a range of different practices, the epistemological model does not appear as a normative model whose organizational principle may be questioned, but as the only conceivable option that constitutes a necessary foundation for all these different practices. The exclusivity of the 
epistemological model, in Taylor's words, exposes a 'forgetting' of why the model once appeared as "an important polemic instrument in the establishing of new forms of scientific thought, and technological, political, ethical practices" (Taylor 1984:30). Taylor's intuition, as described in his Overcoming Epistemology (Taylor 1995:x), is that modern society is different from those of preceding ages (with respect to ethical, political, economic and scientific institutions and practices) in ways that make a crucial difference for the validity of the epistemological model (1995:x). Taylor's perspective is historical. Classical epistemology, in his account, once was a liberating response to the rise of modern mechanistic science. The epistemology that goes back to the Renaissance came to dominate Western thought due to the way it came to be "an important polemic instrument in the establishing of new forms of scientific thought, and technological, political, ethical practices" (1984:30). Taylor's intuition can be understood in light of how Western societies have radically changed along with rapid developments in science and technology during the last century. "The original theory", as Taylor stated, "cannot be understood by practitioners today in the same way as by their predecessors; the attempt to do so results in confusion and muddle. It badly needs reformulation. [...] The society is out of true with the original" (1984:25). Our spontaneous idiomatic expressions, our ways of speaking and thinking about science, technology and society, one could say, need to be restructured in light of how we have come to restructure the practices we live by.

Given the analysis of shared cultural commitments of the representational idiom, and given the emerging quite radical changes in scientific practices, we may better understand why integration is so hard. What is put into motion with calls for integration is some inarticulate understanding of what is important. Integration strategies may intuitively represent an appropriate response to modern science - but may simultaneously come in conflict with a well-established normative order. "The whole strength of the epistemological model lies in the supposed unintelligibility of a rival account", as Taylor said (1984:29).

Taylor's intuition of modern societies as being different compared to the preceding ones finds support in Ziman's analysis of why scientists need to become more ethically sensitive. His argument builds on his analysis of shifting modes of knowledge production that, in his terms, involve a shift from 'academic' to 'post-academic' science (Ziman 2000). He sees the increased call for ethics in the 1990s

as symptomatic of the transformation of science into a new type of social institution. As their products become more tightly woven into the social fabric, scientists have to perform new roles in which ethical considerations can no longer be swept aside (Ziman 1998: $1883)$.

Ethics can no longer be 'swept aside' since science, or at least some sectors of the sciences, has become 'more tightly woven into the social fabric'. Science has changed in ways that call for rethinking of entrenched identities, including norms for how practitioners interact with societal actors.

The important point is that this 'no ethics' principle is not just an obsolete module that can be uninstalled with a keystroke. It is an integral part of a complex cultural form. Merton's norms combine in various ways to motivate and license a wide range of practices and processes (Ziman 1988: 1883).

What Ziman describes as a shift from academic to post-academic science resembles what 
Jerome Ravetz and Silvio Funtowicz (1993) describe as a shift from normal to post-normal science or what Michael Gibbons and his colleagues (1994) describe in terms of Mode 1 and Mode 2. What is striking in all these cases is how the well-established normative order of the normal, academic or Mode 1 is described in recognizable ways - while the alternatives of the post-normal, post-academic and Mode 2 are less developed and remain unclear.

The difficulty of integration and the difficulty of articulating these alternatives are part of the same story. This becomes more evident when we see how the representational idiom expresses not only a 'no ethics' principle, but also a 'no integration' principle. I read the various attempts to clarify the terms of the so-called 'social contract' of the 1990s as part of the work of articulating alternative idioms of science (See, for example, Winner 1993, Guston and Keniston 1994, Lubchenco 1997, Gibbons 1999, Demeritt 2000 and Gallopin et al. 2001). Given a growing awareness of the transformation of science into a new form of social institution, the characteristics of the old institution attracted increasing amounts of interest, as discussed by David Guston's Between Science and Politics (2000), as one example. Science, in Guston's account, has historically come to establish a partnership or 'contract' with society that is perceived as being mutually advantageous. Three elements of this contract clarify how Ziman's 'no ethics' principle simultaneously expresses a 'no integration' principle: i) the linear model, ii) an institutional and conceptual separation between politics and science, and iii) trust.

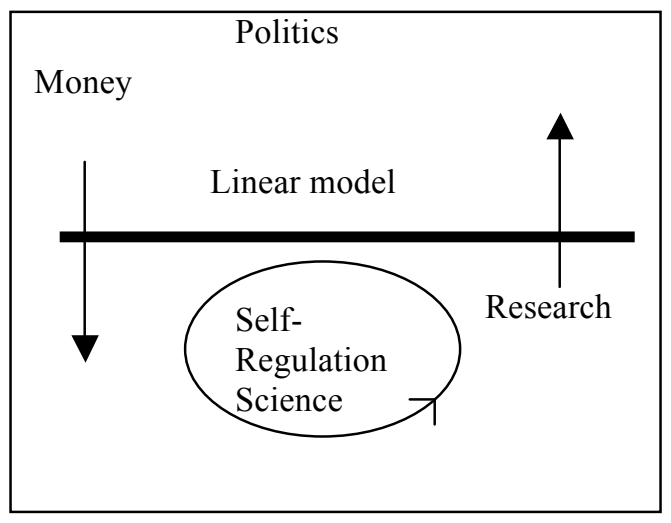

Figure 2. Guston's visualization of the social contract [2000:70]

The linear model expresses assumptions of the dynamics of science that are taken for granted. Basically it assumes the social utility of science, i.e. that research outputs are easily translated into social and economic benefits that will be, by and large, beneficial to society. The reliability of science, upon which its utility depends, is made possible by the institutional and conceptual separation between politics and science. Effective and dedicated self-regulating mechanisms among experts are therefore essential, such as the ones captured in Merton's analysis of the ethos of science. Finally, the contract is based on mutual trust between the scientific community and societal institutions. Politicians and administrators have to trust scientists' self-regulating mechanisms and for their part, scientists need to trust the integrity of the political process.

What is important here is that science is presented as a self-vindicating enterprise that works best when left alone, and as such science should be treated 'as if' it had intrinsic value, and that is not to be interfered with and externally manipulated. Furthermore - the ideals are unifying and constitute a normative order where scientists as well as societal actors should 
make sure that the world of research and facts is kept separate from the world of politics and values. The 'no ethics' principle, then, expresses apolitical and a-ethical ideals of science. The 'no ethics' principle is in fact, tantamount to a ban on integration.

\section{The performative idiom and the critique of the 'no integration' ideal}

Until the 1970s, Michael Lynch and Steve Woolgar (1990) note, there were few incentives for sociologists to study the social and material practices of scientific work, as it was assumed that the identification of the basic characteristic features of the sciences belonged to the realm of epistemology. The shift from the representational to the performative idiom corresponds to what Pickering earlier had described as a tension between conflicting perspectives on science, described in terms of 'science-as-knowledge' on the one hand and 'science-as-practice' on the other (Pickering 1992:vii). The performative idiom was articulated in academic circles that worked differently and could therefore be less bound by traditional 'theory-oriented' theoretical discourses.

The performative idiom, as Pickering described it, expresses a different account of the sciences that emerged in different forms within STS communities during the 1970s and 80s. The concept of the performative idiom is reflected in a variety of studies of the so-called 'laboratory studies' or other studies of 'science-in-practice' (including Latour and Woolgar 1986, Latour 1988, Galison 1987, Fujimura 1996, Knorr-Cetina 1999 or Rheinberger 1997). What is important here is that these works are not marked by the representational idiom, which primarily casts science in terms of an activity that seeks to represent nature. Instead, described simply, the performative idiom regards the world as filled with things that need intervention or with which we have to cope, rather than something we contemplate and observe. In this idiom science is "regarded as a field of powers, capacities, and performances, situated in machinic captures of material agency" (Pickering 1995:7). The performative idiom expresses scientific truths in terms of what we have to deal with, rather than what we may represent correctly, accounting for the epistemic activity of the experimental sciences as one of creating orders or 'stability'.

What is at stake here is not just methodological or epistemic disagreements regarding how science is to be properly conceptualized and studied. The performative idiom challenges normative orders as it casts science in terms crossover crucial technical and social distinctions. These distinctions are essential for the way epistemic and ethical-political debates have been separated, which in turn have framed methodological discussion of how to study science. The performative idiom consequently challenges the 'no integration' ideal because it invites us not to base our analytical work on traditional divisions we presuppose and use all the time in normative analysis (whether they are epistemic or ethical-political).

These studies, to a varying degree, express an implicit critique of the 'no integration' ideal. The influential actor network theory probably makes the challenge more explicit, since the approach constantly traces and displays the exchange, a mixing and a mutual blending of the social and the natural. From this perspective, the object, or the actor network notion of the 'collective' or the 'thing' under consideration, does not fit into these categories, which have been so important for normative reasoning. We are rather invited not to think in terms of distinctions like the 'technical' and 'social', in considering the 'thing' as a dynamic actor network. This perspective promises a study of how things turn out as they do - how actions come to be mediated (Law and Hassard 1999). Getting used to thinking in terms of the performative idiom is challenging, however. From this perspective, science is seen as effective because it violates the no integration ideal. "[T] he more connected a science is to the rest of 
the collective, the better it is, the more accurate, the more verifiable, the more solid" as Bruno Latour (1999:18) put it.

\section{The co-production idiom and the call for integration}

If, or when, one finds these accounts from the 1980s and 1990s convincing and useful, as this paper assumes, the accounts would simultaneously urge one to clarify why we have been committed to the normative distinctions it undermines. We would turn to questions of why it becomes important to safeguard normative divisions of labour and pursue our respective professional work in the ways we have been accustomed to, like what has been done in attempts to articulate the commitments of the social contract of the 1990s. Given Taylor's account of the epistemological model, this work could be seen as part of "undoing the forgetting" of the rationale for the normative order we live by. "We very often cannot raise a new issue really effectively until we have re-articulated our actual practices", Taylor (1984:24) stresses.

Perhaps we now have come to a point where theoretical debates on science are not dominated by the critique of the representational idiom. Perhaps we now can formulate viable alternative accounts of science as part of a slow process of redrafting the social contract of science and society. Part of the challenge is to give further content to key labels like 'postnormal', 'post-academic' or 'Mode 2' science which emphasizes the need to co-think ideals for good science and responsible and just politics. Perspectives on science in which the concerns of good science and good politics are seen as co-evolving, cast science in terms of what Sheila Jasanoff has called 'The Idiom of Co-Production'. Co-production, in Jasanoffs words, "is shorthand for the proposition that the ways in which we know and represent the world (both nature and society) are inseparable from the ways in which we choose to live in it" (Jasanoff 2004:2).

With respect to the dominating representational idiom, co-production represents an important shift in ways that clarify the rationale for integration trends. The co-production idiom cast science in terms that contextualize science while the terms of the representational idiom, in contrast, decontextualize science through a 'theory-oriented' discourse. While the representational idiom committed everyone to a 'no integration' ideal to safeguard the science politics distinction, the co-production idiom focus obligates everyone to understand how science and politics are intrinsically linked and take appropriate actions.

Integration, then, is seen here as a key notion of the co-production idiom of science, including its relation to technological and societal activities. It is a key notion in a normative sense, as the 'no-integration' principle of the representational idiom corresponds to Ziman's 'no ethics' principle. If the ways we 'know the world' are inseparable from the ways we 'chose to live in it', the 'no ethics' principle, safeguarded by the 'no integration' principle loses its legitimacy. The call for integration can be seen as a call for the 'integration of ethics', although the term 'ethics' in this context often serves as a placeholder for a wide set of interlinked concerns, as is expressed in the ELSA acronym.

Integration is perhaps first of all a key notion of the co-production idiom in a methodological sense. The co-production idiom call attention to the need to co-think practices that the representational idiom urges us to keep separate. This consequently makes integration efforts difficult as they can be seen as deliberate attempts to repair deficiencies in practices to which we are collectively committed, while we simultaneously lack a shared analysis of how to structure our intuition of these deficiencies and how to repair them. Much attention has been paid to the need for working out new methods, by experimenting with collaborations between scientists and researchers from the humanities or the social sciences, 
or by engaging societal concern through public engagement (Rowe and Frewer 2000, Fisher et al. 2015). Discussions of the hows and whys of these efforts, as well as the search for other imaginative strategies for integration, suffer from the lack of a viable alternative to the normative order of the representational idiom.

The growing numbers of policy documents that call for integration, such as the Nano 2021 program plan, bear witness to a co-production image of science. The presentation of the nanotechnology research field shown in Figure 1 illustrates integration as a proper response to, as well as a key challenge to, modern science. A ten-year-old EU report, Converging Technologies. Shaping the Future of European Societies (Nordmann 2004) is likewise illustrative. The report argues that integrative measures are needed, because like it or not, the new converging technologies (typically biotechnology and nanotechnology) will shape the future of European societies. The report thus argues for "widening the circles of convergence" to include the research input of the social sciences and the humanities. Given the dominance of the representational idiom, the message of these policy documents is quite striking, as it seems to express some agreement across sectors of the appropriateness of the co-production idiom.

\section{The difficulty of integration}

This paper takes a historic perspective. The fact that common understandings of the sciences change does not necessarily imply that earlier generations were wrong. Contemporary calls for the integration of ethics do not necessarily express a reaction to some form of moral degeneration. What used to be good, responsible ways of organizing research may simply not be suited to our time. What is needed is to find proper responses to urgent contemporary concerns.

In Taylor's analysis, the representational account of knowledge has come to be an unfortunate barrier for normative thinking in Western societies, which would include our understanding of the sciences. We may read the call for integration as a symptom. When the notion of science is cast in the representational idiom, where science is seen as an activity that seeks to represent nature, it simultaneously includes guidelines for how the relationships between science, technology and society should ideally be modelled. The need for the integration of ethics may be interpreted as a shared, more-or-less articulated intuition across sectors that the model needs to be revised. However, the commitment to the model has been so strong, and is so entrenched in a wide set of practices, that it is still difficult to imagine alternatives.

Given this analysis, finding an alternative is not a matter of pulling together a clever theory of co-production. It is a question of how to simultaneously re-articulate ideals of good scientific and good political practices as scientific activities are seen as coupled to political activities. This task involves connecting the epistemic and the ethical-political normative discussions which we have committed to keep separate. Taylor discusses the matter in in "Explanation and Practical Reason".

[T] he activity of explaining why things are as they are (what we think of as science) is intrinsically linked to the activity of determining what the good is, and in particular how human beings should live through attuning themselves to this order. The notion that explanation can be distinct from practical reason, that the attempt to grasp what the world is like can be made independent of the determination of how we should stand in it, that the goal of understanding the cosmos can be uncoupled from our attunement to it, this makes no sense in the premodern understanding. But notoriously the 
seventeenth-century revolution brought about an uncoupling of just this kind (Taylor 1995:45).

The epistemic discussion of good science (which explains how the sciences can capture how things are as they are) is not to be uncoupled from the ethical and political activity of determining the good. The call for 'integrating ethics', in this paper, is seen as a call for recoupling what the representational idiom notoriously urges us to decouple.

The theoretical mistake, if one may use such a phrase, is to regard the social contract as ahistorical, and thereby to perceive it as the only available option for how scientific and political activities should be coupled. Integrating ethics into science is not a plea for integrating ethics into a discipline in need of ethical and political add-ons. Integrating ethics expresses a need for articulations of science that cross over the two normative concerns, the epistemic and ethico-political. The story of three successive idioms may provide reasons for defending experiments on integration that have a normative aim. Integrative experimental approaches that aim at finding viable answers to urgent challenges may simultaneously engage in the work of articulating a viable theory of co-production. Such theories may help improve our understanding of current research structures and thereby provide a frame for discussions of how to meet the challenges of our time.

\section{References}

Balmer, A., Bulpin, K., Calvert, J., Kearnes, M., Mackenzie, A., Marris, C., Martin, P., Molyneux-Hodgson, S. and Schyfter, P. (2012) Towards a Manifesto for Experimental Collaborations between Social and Natural Scientists. http://experimentalcolla borations. wordpress.com/ Accessed 12 February 2013.

Boyle, J. (1984) The Humanities and the Professions: The Rise of Bioethics. The Iowa Review, 14 (3) p.151-159.

Brandt, A. (2002) Bioethics - Then and Now. Harvard Health Policy Review, 3 (1) p.1-2. http://www.hcs.harvard.edu/ epihc/currentissue/spring2002/brandt.php

Cook-Deegan, R. (1995) The Gene Wars: Science, politics, and the Human Genome. New York: Norton.

Demeritt, D. (2000) The New Social Contract for Science: Accountability, Relevance, and Value in US and UK Science and Research Policy. Antipode, 32, p. 308-329.

EC (2013) Options for Strengthening Responsible Research and Innovation. European Commission report, Brussels. http://ec.europa.eu/research/swafs/pdf/pub_public_ engagement/options-for-strengthening_en.pdf (Accessed March 2015)

EC (2004) Converging Technologies - Shaping the Future of European Societies. European Commission report, Brussels. http://www.ntnu.no/2020/final_report_en.pdf Accessed March 2015.

EC (2007) Taking European Knowledge Society Seriously. Report of the Expert Group on Science and Governance to the Science, Economy and Society Directorate, Directorate-General for Research, European Commission. https://www.bmbf.de/pub/ EuropeanKnowledge\%286\%29.pdf (Accessed March 2015)

Fisher, E., Mahajan, R.L. and Mitcham, C. (2006) Midstream Modulation of Technology: Governance From Within. Bulletin of Science, Technology \& Society (26) p.485-496. 
Fisher, E. O’Rourke, M., Evans, R., Kennedy, E., Gorman, M. and Seager, T. (2015) Mapping the integrative field: taking stock of socio-technical collaborations. Journal of Responsible Innovation. Published online 2. March 2015. http://www.tandfonline. com/doi/abs/10.1080/23299460.2014.1001671\#.VRZ_beGyKdw

Fujimura, J. H. (1996) Crafting Science. A Sociohistory of the Quest for the Genetics of Cancer. Cambridge: MIT Press.

Funtowicz, S. and Ravetz, J. R. (1993) Science for the post-normal age. Futures, 25, p.739-755.

Galison, P. (1987) How Experiments End. Chicago: University of Chicago Press.

Gallopin, G., Funtowicz. S., O'Connor, M. and Ravetz, J. (2001) Science for the Twenty-First Century: From Social Contract to the Scientific Core. International Social Science Journal, 53, p219-229.

Gibbons, M., Limoges, C., Nowotny, H., Schwartzman, S., Scott, P., and Trow, M. (1994) The New Production of Knowledge. London: Sage Publications.

Gibbons, M. (1999) Science's New Social Contract With Society. Nature, 402, p. 81-84.

Guston, D. and Sarewitz, D. (2002) Real-time Technology Assessment. Technology in Society, 24, p. 93-109.

Guston, D. (2000) Between Politics and Science: Assuring the Integrity and Productivity of Research. Cambridge: Cambridge University Press.

Guston, D. and Keniston, K. (1994) Updating the Social Contract for Science. Technology Review, 97, p. 60-69.

Hacking, I. (1983) Representing and Intervening. Cambridge: Cambridge University Press.

Jasanoff, S. (2004) The Idiom of Co-Production. In Jasanoff, S. (ed.) States of Knowledge: The Co-production of Science and the Social Order. London: Routledge.

Lubchenco, J. (1997) "Entering the Century of the Environment: A New Social Contract for Science". Science, 279, p.491-497.

Knorr-Cetina, K. (1999) Epistemic Cultures: How the Sciences Make Knowledge. Cambridge: MIT Press.

Latour, B. (1988) The Pasteurization of France. Cambridge: MIT Press.

Latour, B. (1999) Pandora's Hope. Essays on the Reality of Science Studies. Cambridge: Harvard University Press.

Latour, B. and Woolgar, S. (2.ed.) (1986) Laboratory Life: The Construction of Scientific Facts. Princeton: Princeton University Press.

Law, J. and Hassard, J. (eds.) (1999) Actor Network Theory and After. Oxford: Blackwell Publishers.

Lynch, M. (1993) Scientific practice and Ordinary Action. Cambridge: Cambridge University press.

Lynch, M. and Woolgar, S. (1990) Introduction. Sociological Orientations to Representational Practice in Science. In Lynch, M. and Woolgar, S. (eds) Representation in Scientific Practice. Cambridge: MIT Press.

Merton, R.K. (1942) Science and democratic social structure. Reprinted in Merton R.K. 1968 Social Theory and Social Structure. New York: Free Press.

Meslin, E., Thomson, E. and Boyer, J. (1997) Bioethics inside the beltway. The Ethical, Legal, and Social Implications Research Program at the National Human Genome Research Institute. Kennedy Institute of Ethics Journal, 7 (3), p.291-298.

Myskja, B. K., Nydal, R. and Myhr, A. I. (2014) We have never been ELSI researchers - there is no need for a post-ELSI shift. Life Sciences, Society and Policy, 10 (9) http://www.lsspjournal.com/content/10/1/9

Nature [editorial] (2009) Mind the gap. Nature 462, p.825-836 
NAF (2006) Environmental, Social, Legal and Ethical Aspects of The Development of Nanotechnologies in Australia. A report for The National Nanotechnology Strategy Taskforce. Department of Industry Tourism and Resources. Parville Vic: National Academics Forum.

Nano2021 (2013) Work programme 2012-2021 Nanotechnology and Advanced Materials NANO2021. Oslo: The Research Council of Norway. Available from http://www.forskningsradet.no/

NFR (2005) Nanoteknologier og nye materialer: Helse, miljø, etikk og samfunn. Oslo: Norges forskningsråd. Available from http://www.forskningsradet.no/

NFR (2008) Work Program 2008-2014. Ethical, Legal and Social Aspects of Biotechnology, Nanotechnology and Neurotechnology - ELSA. Oslo: NFR. Available from http://www.forskningsradet.no/

NFR (2014) SAMANSVAR work programme 2015-2024. Programme on Responsible Innovation and Corporate Social Responsibility. Oslo: NFR. Available from http://www.forskningsradet.no/

Nielsen, T.H. (2006) Fristere og syndere i det universitets-industrielle kompleks - apropos tilfældene Hwang og Schön. In Nydal, R. and Solberg, B. (red.), Juks, uredelighet og god forskning. Trondheim: Tapir Akademisk Forlag. p.49-56.

Nydal, R. (2005) Rethinking the topoi of normativity. Philosophical dissertation: Trondheim NTNU. http://brage.bibsys.no/xmlui/handle/11250/242782?locale-attribute $=$ no

NSF (2001) Societal Implications of Nanoscience and Nanotechnology. Report from the Workshop held at the National Science Foundation, 28-29. September, 2000.

Owen, R., Bessant,J. and Heintz, M. (2013) (eds.). Responsible Innovation: Managing the Responsible Emergence of Science and Innovation in Society. Chichester: Wiley Press

Pickering, A. (1992) (ed.) Science as Practice and Culture. Chicago: Chicago University Press.

Pickering, A. (1995) The Mangle of Practice. Time, Agency and Science. Chicago: Chicago University Press.

Rip, A. (2014) The past and future of RRI. Life Sciences Society and Policy 10:17

Rip, A., Schot, J.W and Misa, T.J. (1995) (eds.) Managing Technology in Society. The Approach of Constructive Technology Assessment. London and New York: Pinter publishers.

RAE (2004) Nanoscience and Nanotechnologies: Opportunities and uncertainties. London: Royal Society and Royal Academy of Engineering.

Rheinberger, H-J. (1997) Toward a History of Epistemic Things. Synthesizing Proteins in the Test Tube. Stanford: Stanford University Press.

RNA (2004) How big can small actually be? Some remarks on research at the nanometre scale and the potential consequences of nanotechnology. Prepared for the Dutch Minister of Education, Culture and Science. Amsterdam: Royal Netherlands Academy of Arts and Sciences.

Roberts, L. (2001) Controversial From the Start. Science 291, p.1182-1188.

Rorty, R. (1980) Philosophy and the Mirror of Nature. Princeton: Princeton University Press.

Rowe, G. and Frewer, L.J. (2000) Public participation methods: a framework for evaluation. Science, Technology \& Human Values, 25, p.3-29.

Schot, J. and Rip, A. (1996) The Past and Future of Constructive Technology Assessment, Technological Forecasting and Social Change, 54, p.251-268.

Taylor, C. (1984) Philosophy and Its History. In Rorty, R., Schneewind, J. B. and Skinner, Q. (eds.) Philosophy in History. Cambridge: Cambridge University Press.

Taylor, C. (1985) Philosophy and the Human Sciences. Philosophical Papers II. Cambridge: Cambridge University Press. 
Taylor, C. (1995) Philosophical Arguments. Cambridge: Harvard University Press.

Toulmin, S. (1982) How medicine saved the life of ethics. Perspectives in Biology and Medicine, 25, p.736-750.

Williams, R. (2006) Compressed Foresight and Narrative Bias: Pitfalls in Assessing High Technology Futures. Science as Culture, 15, (4) p.327-348.

Winner, L. (1993) A New Social Contract for Science. Technology Review 96, p.65.

Winner, L. (2004) Testimony to the Committee on Science of the U.S.S House of Representatives on The Societal Implications of Nanotechnology. Wednesday, April 9, 2003. http://www.rpi.edu/ winner/testimony.htm Accessed 17 February 2011.

Ziman J. (1998) Why Must Scientists become More Ethically Sensitive than They Used to be? Science, 282, p.1813-1814.

Ziman J. (2000) Real Science. What it is, and what it means. Cambridge: Cambridge University Press. 